\title{
Direct Production of High Pressure Hydrogen at Great Rate from Glycerol/Water/Metal Mixture
}

\author{
Seiichi Deguchi', Norifumi Isu ${ }^{2}$, Noriyuki Kobayashi' ${ }^{3}$, Hajime Ohtani ${ }^{4}$, Saeko Miwa ${ }^{1}$, \\ Mitsunori Ito ${ }^{1}$ \\ ${ }^{1}$ Department of Energy Engineering and Science, Nagoya University, Nagoya, Japan \\ ${ }^{2}$ Kitchen and Bathroom Technology Research Institute, LIXIL Corporation, Tokoname, Japan \\ ${ }^{3}$ Department of Chemical Engineering, Nagoya University, Nagoya, Japan \\ ${ }^{4}$ Department of Life Science and Applied Chemistry, Nagoya Institute of Technology, Nagoya, Japan \\ Email: deguchi@nuce.nagoya-u.ac.jp
}

Received 11 June 2016; accepted 13 August 2016; published 16 August 2016

Copyright (C) 2016 by authors and Scientific Research Publishing Inc.

This work is licensed under the Creative Commons Attribution International License (CC BY). http://creativecommons.org/licenses/by/4.0/

(c) (i) Open Access

\section{Abstract}

One of the key issues facing the global society today is to find renewable and sustainable energy sources. Hydrogen has gained much attention in recent years since it is one of fuels for fuel cells. It emits no carbon dioxide when it is used and so on. In this study, a great rate production of high pressure hydrogen rich gas from glycerol/water/metal mixtures was developed since glycerol has become one of the enormous industrial by-products, especially from biodiesel processing plants. It was found that cobalt was the optimum metal additive among tested metals of aluminum, cobalt, magnesium and nickel in terms of a hydrogen producing rate, a hydrogen partial pressure and a conversion ratio from $50 \mathrm{~mol} \%$ glycerol/water mixtures under an operating temperature of $723 \mathrm{~K}$. Concretely, hydrogen rich gas with concentration about $64 \% \mathrm{H} 2$ and high partial pressure about $4 \mathrm{MPa}_{\mathrm{N}, \mathrm{H} 2}$ could be produced at the great producing rate of 42.9 $\mathrm{L}_{\mathrm{N}, \mathrm{H} 2} \mathrm{dm}^{-2} \mathrm{~min}^{-1}$ and high conversion ratio about $60 \%{ }_{\mathrm{H} 2}$. All the produced hydrogen rich gases from glycerol/water/metal mixtures were by no means inferior to pure hydrogen as a fuel for the polymer electrolyte fuel cell.

\section{Keywords}

Great-Rate Hydrogen Production, High Pressure Hydrogen, Glycerol Reforming, Sustainable Energy 


\section{Introduction}

The current generation has been faced with many serious problems such as global warming and exhaustion of fossil fuels. Hydrogen is one of the most promising alternative energies since it emits no carbon dioxide when it is used to power fuel cells, which must be indispensable technology for the next generation to keep anthropic activities.

There are so many methods to produce hydrogen such as water electrolysis led as World Energy Network (WE-NET) project, thermal, biochemical, photonic, electro-thermal, photo-electric and photo-biochemical processes [1]-[5]. However, the methane steam reforming is still the most vital route for hydrogen production [6]. In order to establish a sustainable hydrogen society, to find fossil-fuel-free and exhaustless hydrogen sources is one of the key issues during the coming decades.

Here, extrapolating trials of the developed annealing processes of inorganic powders in critical media [7] incidentally provided high pressure hydrogen rich gases from methanol/water and ethanol/water with some metals additive under relatively low temperatures ranging from 573 to $723 \mathrm{~K}$ [8]. To make these incidental phenomena into significant steps for realizing the sustainable hydrogen society, survey of enormous wasted alcohols from any industries had been performed, leading to glycerol which is the main by-product from biodiesel processing plants, emerged as one of the potential candidates.

Glycerol already attracted much attention as one of the semi-exhaustless hydrogen sources since it has the noteworthy character of decentralized chemical species [9]. And, its popular reforming methods are biological fermentation and catalytic steam reforming [9]-[14]. Rather low hydrogen producing rates of a few and below $\mathrm{L}_{\mathrm{N}} \mathrm{dm}^{-3} \mathrm{hr}^{-1}$ have been achieved by the biological fermentations. High operating temperatures around $850 \mathrm{~K}$ have been reported favorable for the catalytic steam reforming to yield improved conversion ratios with preventing carbon deposits on the catalysts simultaneously. Kinetic investigations of the catalytic glycerol steam reforming are still scarce in contrast to massive equilibrium outcomes.

In this study, kinetic experiments of glycerol reforming reactions with various metals additive were carried out in the aims of achieving a great hydrogen producing rate and a high hydrogen partial pressure. The optimal operating conditions are specified clearly. Further potential strategies for the higher hydrogen partial pressure and the grater hydrogen producing rate are logically discussed.

\section{Experimental}

\subsection{Experimental Apparatus}

Figure 1 shows a schematic drawing of the prototype high-pressure hydrogen producing apparatus.

The main body was made of a SUS304 pipe with a 1/4 inch outer diameter and $200 \mathrm{~mm}$ height. Inside volume of the prototype apparatus was roughly $31 \mathrm{~mL}$, including the upper part with SUS304 joints, a pressure indicator, a safety valve and a gas sampling tap attached. The inside pressure displayed by the pressure indicator could be recorded by a remote monitoring system consisted of a web-camera and a PC data logger. The safety valve was set so that it was automatically opened if the inside pressure surpassed $15 \mathrm{MPa}$.

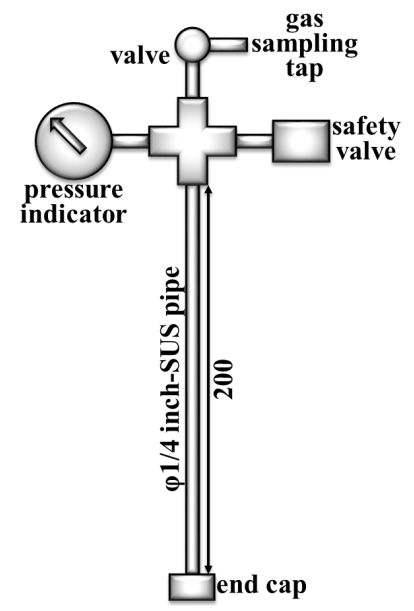

Figure 1. Schematic drawing of apparatus. 


\subsection{Experimental Procedures}

Firstly, $1.5 \mathrm{~mL}$ of $50 \mathrm{~mol} \%$ glycerol/water mixture and $0.5 \mathrm{~g}$ of a metal additive were fed into the main body with an end cap. The tested metals, which were all reagent grade, were aluminum, cobalt, magnesium and nickel. Then, the upper part was mounted, creating an airtight system. The gas initially presented inside the apparatus was vacuumed out, resulting the inside pressure less than 30 torr. The main body of the apparatus was submersed in a water bath, and then ultrasonic waves were irradiated for 30 min to homogenize all materials inside the pipe (US-5, SND Japan, bath volume: $20 \mathrm{~L}$, ultrasonic frequency: $38 \mathrm{kHz}$, output power: $300 \mathrm{~W}$ ).

The experiments were started by inserting the main body into a cylindrical electric furnace preheated up to a preset operating temperature. When the inside pressure reached equilibrium value or surpassed $15 \mathrm{MPa}$, the main body was immersed in a large water bath at a room temperature for immediate quenching to cease any reactions. The chemical composition of the produced gas was measured by means of TCD gas-chromatography.

\subsection{Estimating Way for Hydrogen Producing Rate}

Since very small amount of hydrogen was detected in the case without metals additive, any metals composing the prototype apparatus of SUS304 could be confirmed to have no capabilities to reform glycerol/water mixture.

Figure 2 shows time trends of the inside pressures with respect to metals additive. The measured hydrogen concentrations of the produced hydrogen rich gases are also filled in. It can be seen that the inside pressures proportionally increase over time as denoted by semi-transparent gray belts after respective initiating times less than 5 min before starting glycerol reforming reactions (i.e. generation of gases including hydrogen).

Assuming that the hydrogen concentration through each experiment had been invariable, the hydrogen producing rate could be estimated from proportionally increasing speed of the inside pressure towards time under an ideal gas approximation as well.

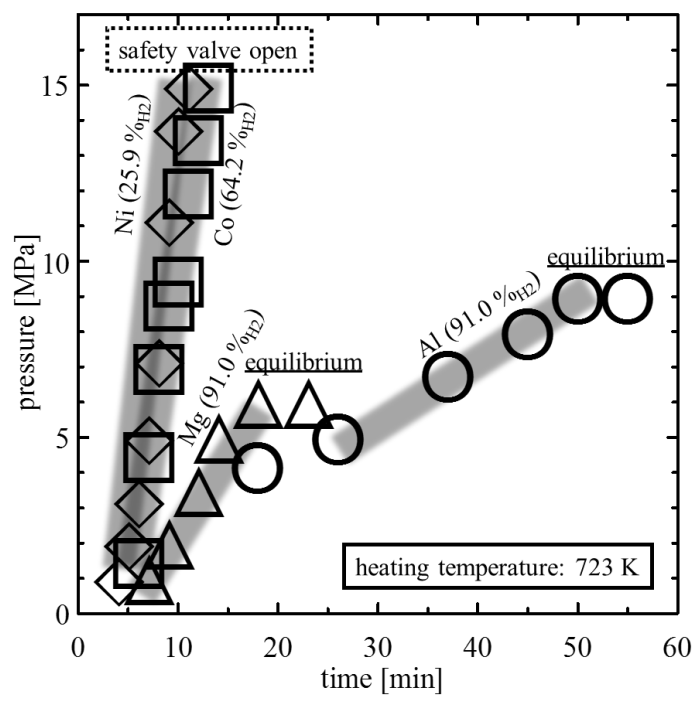

Figure 2. Time trend of pressure inside the apparatus with various metals additive.

\section{Results and Discussions}

\subsection{Overview of Hydrogen Productions from Glycerol/Water/Metal Mixtures at $723 \mathrm{~K}$}

Here, all the produced hydrogen rich gases from glycerol/water/metal mixtures were confirmed by no means inferior to a commercially available pure hydrogen as a fuel for the polymer electrolyte fuel cell, irrespective of their relatively low hydrogen concentrations as filled in Figure 2. Consequently, the central characteristics forming the core of this hydrogen rich gas production via glycerol reforming reactions with metals additive turn to be the hydrogen producing rate and the hydrogen partial pressure for its space-saving design so as to be applied to fuel cell systems, fuel cell vehicles, and so forth. 
To compare these two central characteristics described in the previous paragraph viscerally, Figure 3 shows time trends of the hydrogen partial pressures converted at the normal condition with respect to metals additive. All of their base measured pressures behind are shown in Figure 2. Each of plots in Figure 3 is from the measured pressure on the assumption of the invariable hydrogen concentration throughout each experiment, taking into consideration the ideal gas approximation and the operating temperature as well.

Steep increases in the hydrogen partial pressure towards time as denoted by semi-transparent gray belts (i.e. great-rate hydrogen production) can be clearly seen in Figure 3, excepting the case with aluminum additive. Since the safety valve opened before the inside pressure reached equilibrium value in the cases with cobalt and nickel additive, further potentials for higher hydrogen partial pressures still remain due to minor alternations of the prototype high-pressure hydrogen producing apparatus.

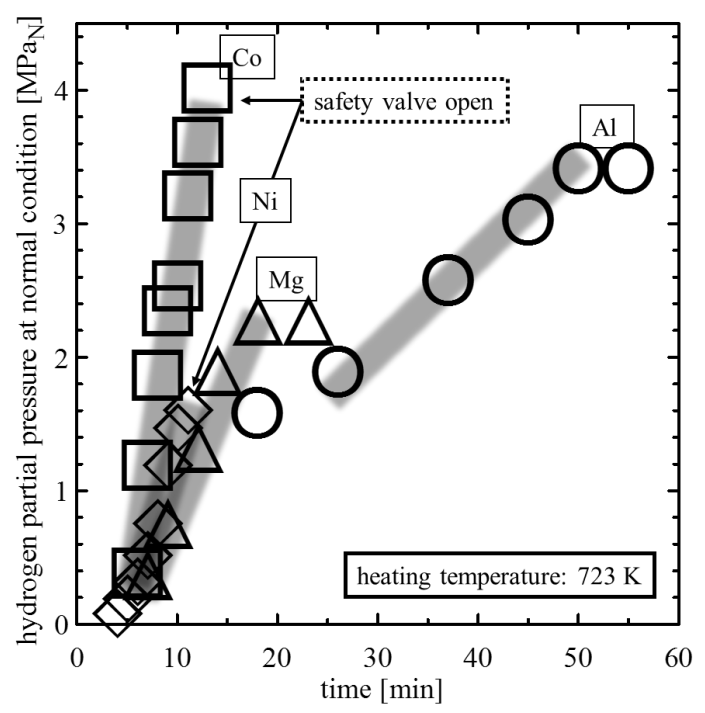

Figure 3. Time trend of hydrogen partial pressure at normal condition with various metals additive.

\subsection{Optimal Metal Additive}

Table 1 shows the concrete values including the two central characteristic values with various metals additive tested, excluding the case with aluminum additive.

Among tested, cobalt can be concluded the optimal metal additive for currently investigated hydrogen rich gas producing process via glycerol reforming reactions with metals additive. Concretely, hydrogen rich gas with the high partial pressure $4.04 \mathrm{MPa}_{\mathrm{N}, \mathrm{H} 2}$ could be produced at the great rate $42.9 \mathrm{~L}_{\mathrm{N}, \mathrm{H} 2} \mathrm{dm}^{-2} \mathrm{~min}^{-1}$ and the high conversion ratio $60.9 \%_{\mathrm{H} 2}$. Accordingly, cobalt has been used in the following experiments.

Table 1. Hydrogen productions with various metals additive.
\begin{tabular}{cccc}
\hline Fixed Condition & \multicolumn{3}{c}{ Operating Temperature: $723 \mathrm{~K}$} \\
\hline \multirow{2}{*}{ Metal Additive } & \multicolumn{3}{c}{ Characteristics of Produced Hydrogen Rich Gas } \\
\cline { 2 - 4 } & Partial Pressure & Producing Rate & Conversion Ratio \\
\hline $\mathrm{Co}$ & $4.04 \mathrm{MPa}_{\mathrm{N}, \mathrm{H} 2}$ & $42.9 \mathrm{~L}_{\mathrm{N}, \mathrm{H} 2} \mathrm{dm}^{-2} \mathrm{~min}^{-1}$ & $60.9 \%$ \\
$\mathrm{Mg}$ & $2.29 \mathrm{MPa}_{\mathrm{N}, \mathrm{H} 2}$ & $15.0 \mathrm{~L}_{\mathrm{N}, \mathrm{H} 2} \mathrm{dm}^{-2} \mathrm{~min}^{-1}$ & $43.0 \%$ \\
$\mathrm{Ni}$ & $1.63 \mathrm{MPa}_{\mathrm{N}, \mathrm{H} 2}$ & $19.8 \mathrm{~L}_{\mathrm{N}, \mathrm{H} 2} \mathrm{dm}^{-2} \mathrm{~min}^{-1}$ & $21.4 \%$ \\
\hline
\end{tabular}

\subsection{Effect of Temperature on Hydrogen Rich Gas Production}

Figure 4 shows time trends of the hydrogen partial pressure at the normal condition from glycerol/water/cobalt 
mixtures under an operating temperature of $573 \mathrm{~K}$ together with that under $723 \mathrm{~K}$, which is completely the same as shown in Figure 3.

Naturally, slower increase in the hydrogen partial pressure towards time can be obtained at the lower operating temperature of $573 \mathrm{~K}$. In order to evaluate the effect of temperature on the hydrogen rich gas production from glycerol/water/cobalt mixtures, the important values are collected up in Table 2. Table 2 also includes the concrete values in the cases with other metals additive of aluminum, magnesium and nickel as bases for quantitative comparisons to discuss for the optimal operating temperature.

The obtained hydrogen producing rate $1.96 \mathrm{~L}_{\mathrm{N}, \mathrm{H} 2} \mathrm{dm}^{-2} \mathrm{~min}^{-1}$ and hydrogen partial pressure $1.90 \mathrm{MPa}_{\mathrm{N}, \mathrm{H} 2}$ from glycerol/water/cobalt mixture at $573 \mathrm{~K}$ are supposed not so bad values in contrast to the cases with other metals additive at $723 \mathrm{~K}$, taking heating temperature differences into consideration. Therefore, it is found that this hydrogen rich gas production via glycerol reforming reactions with cobalt additive is workable under quite a low temperature of $573 \mathrm{~K}$.

Nevertheless, far better hydrogen producing rate and hydrogen partial pressure (i.e. great rate of hydrogen production $42.9 \mathrm{~L}_{\mathrm{N}, \mathrm{H} 2} \mathrm{dm}^{-2} \mathrm{~min}^{-1}$ and quite high hydrogen partial pressure $4.04 \mathrm{MPa}_{\mathrm{N}, \mathrm{H} 2}$ ) from glycerol/water/ cobalt mixture at $723 \mathrm{~K}$ can be realized. Moreover, the operating temperature of $723 \mathrm{~K}$ is rather low, comparing with other hydrogen producing methods such as methane steam reforming, UT-3 and IS process [2] [15]-[17]. Then, operating temperatures around $723 \mathrm{~K}$ and above are concluded favorable for this hydrogen rich gas production via glycerol reforming reactions with cobalt additive in terms of the great hydrogen producing rate and high hydrogen partial pressure in the produced hydrogen rich gases.

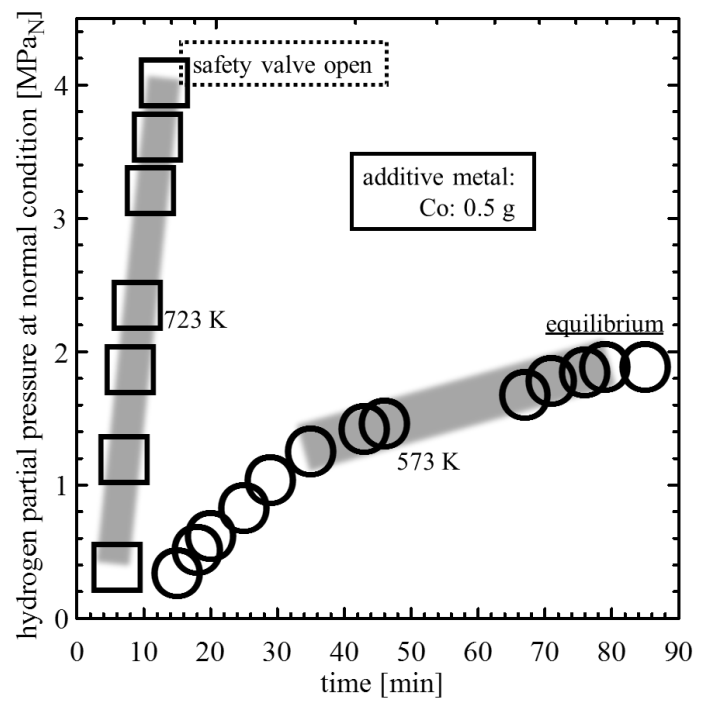

Figure 4. Time trend of hydrogen partial pressure at normal condition with respect to temperature.

Table 2. Important values of hydrogen rich gases from glycerol/water/metal mixtures.

\begin{tabular}{|c|c|c|c|c|c|}
\hline \multirow[b]{2}{*}{ Temperature } & \multirow{2}{*}{$\begin{array}{c}\text { Metal } \\
\text { Additive }\end{array}$} & \multicolumn{4}{|c|}{ Characteristics of Produced Hydrogen Rich Gas } \\
\hline & & $\begin{array}{c}\text { Hydrogen } \\
\text { Concentration }\end{array}$ & Partial Pressure & Producing Rate & Conversion Ratio \\
\hline $573 \mathrm{~K}$ & Co & $40.0 \%{ }_{\mathrm{H} 2}$ & $1.90 \mathrm{MPa}_{\mathrm{N}, \mathrm{H} 2}$ & $1.96 \mathrm{~L}_{\mathrm{N}, \mathrm{H} 2} \mathrm{dm}^{-2} \mathrm{~min}^{-1}$ & $39.0 \%$ \\
\hline $723 \mathrm{~K}$ & $\mathrm{Co}$ & $64.2 \% \mathrm{H}_{2}$ & $4.04 \mathrm{MPa}_{\mathrm{N}, \mathrm{H} 2}$ & $42.9 \mathrm{~L}_{\mathrm{N}, \mathrm{H} 2} \mathrm{dm}^{-2} \min ^{-1}$ & $60.9 \%$ \\
\hline $723 \mathrm{~K}$ & $\mathrm{Al}$ & $91.0 \%{ }_{\mathrm{H} 2}$ & $3.43 \mathrm{MPa}_{\mathrm{N}, \mathrm{H} 2}$ & $5.2 \mathrm{~L}_{\mathrm{N}, \mathrm{H} 2} \mathrm{dm}^{-2} \mathrm{~min}^{-1}$ & $49.0 \%$ \\
\hline $723 \mathrm{~K}$ & $\mathrm{Mg}$ & $91.0 \% \%_{\mathrm{H} 2}$ & $2.29 \mathrm{MPa}_{\mathrm{N}, \mathrm{H} 2}$ & $15.0 \mathrm{~L}_{\mathrm{N}, \mathrm{H} 2} \mathrm{dm}^{-2} \mathrm{~min}^{-1}$ & $43.0 \%$ \\
\hline $723 \mathrm{~K}$ & $\mathrm{Ni}$ & $25.9 \%{ }_{\mathrm{H} 2}$ & $1.63 \mathrm{MPa}_{\mathrm{N}, \mathrm{H} 2}$ & $19.8 \mathrm{~L}_{\mathrm{N}, \mathrm{H} 2} \mathrm{dm}^{-2} \min ^{-1}$ & $21.4 \%$ \\
\hline
\end{tabular}




\section{Conclusions}

A grate rate production of high pressure hydrogen rich gases from glycerol/water/metal mixtures was experimentally developed.

The results indicated that cobalt was the optimum metal additive in terms of a hydrogen producing rate, a hydrogen partial pressure and a conversion ratio. Concretely, hydrogen rich gas with the high hydrogen partial pressure about $4 \mathrm{MPa}_{\mathrm{N}, \mathrm{H} 2}$ could be produced at the great producing rate of $42.9 \mathrm{~L}_{\mathrm{N}, \mathrm{H} 2} \mathrm{dm}^{-2} \mathrm{~min}^{-1}$ and high conversion ratio $60.9 \%{ }_{\mathrm{H} 2}$.

\section{Acknowledgements}

This work is supported by "General Sekiyu R\&D Encouragement Assistance Foundation" and "Tanikawa Fund Promotion of Thermal Technology". These financial supports are gratefully acknowledged. Seiichi Deguchi would like to express deep gratitude to the late Mr. Tatsumi Imura for his kindhearted encouragements and helpful suggestions for executing the experiments before he passed away.

\section{References}

[1] Iwasaki, W. (2003) A Consideration of Power Density and Hydrogen Production and Utilization Technologies. International Journal of Hydrogen Energy, 28, 1325-1332. http://dx.doi.org/10.1016/S0360-3199(03)00040-5

[2] Dincer, I. and Acar, C. (2015) Review and Evaluation of Hydrogen Production Methods for Better Sustainability. International Journal of Hydrogen Energy, 40, 11094-11111. http://dx.doi.org/10.1016/j.ijhydene.2014.12.035

[3] Deguchi, S., Takeichi, T., Shimasaki, S., Ogawa, M. and Isu, N. (2011) Photocatalytic Hydrogen Production from Water with Nonfood Hydrocarbons as Oxidizing Sacrifice Agents. AIChE Journal, 57, 2237-2243. http://dx.doi.org/10.1002/aic.12414

[4] Deguchi, S., Kariya, B., Isu, N., Shimasaki, S., Banno, H., Miwa, S., Sawada, K., Tsuge, J., Imaizumi, S., Kato, H. and Tokutake, K. (2014) Enhancement of Photocatalytic Water Splitting Rate via Rayleigh Convection. Green and Sustainable Chemistry, Scientific Research, 4, 80-86. http://dx.doi.org/10.4236/gsc.2014.42012

[5] Banno, H., Kariya, B., Isu, N., Ogawa, M., Miwa, S., Sawada, K., Tsuge, J., Imaizumi, S., Kato, H., Tokutake, K. and Deguchi, S. (2014) Effect of $\mathrm{TiO}_{2}$ Crystallite Diameter on Photocatalytic Water Splitting Rate. Green and Sustainable Chemistry, Scientific Research, 4, 87-94. http://dx.doi.org/10.4236/gsc.2014.42013

[6] Angeli, S.D., Monteleone, G., Giaconia, A. and Lemonidou, A.A. (2014) State-of-the-Art Catalysts for $\mathrm{CH}_{4} \mathrm{Steam}$ Reforming at Low Temperature. International Journal of Hydrogen Energy, 39, 1979-1997. http://dx.doi.org/10.1016/j.ijhydene.2013.12.001

[7] Deguchi, S., Ogawa, M., Nowak, W., Wesolowska, M., Miwa, S., Sawada, K., Tsuge, J., Imaizumi, S., Kato, H., Tokutake, K., Niihara, Y. and Isu, N. (2013) Development of Super- and Sub-Critical Water Annealing Processes. Powder Technology, 249, 163-167. http://dx.doi.org/10.1016/i.powtec.2013.08.013

[8] Miwa, S., Ito, M., Shimasaki, S., Ogawa, M., Banno, H., Sawada, K., Ohtani, H., Higashijima, Y., Niihara, Y., Terasawa, K., Isu, N. and Deguchi, S. (2014) Hydrogen Producing Device. Japanese Open Patent No. 2014-037323.

[9] Schwengber, C.A., Alves, H.J., Schaffner, R.A., Silva, F.A., Sequinel, R., Bach, V.R. and Ferracin, R.J. (2016) Overview of Glycerol Reforming for Hydrogen Production. Renewable and Sustainable Energy Reviews, 258, 259-266. http://dx.doi.org/10.1016/j.rser.2015.12.279

[10] Dieuzeide, M.L., Laborde, M., Amadeo, N., Cannilla, C., Bonura, G. and Frusteri, F. (2016) Hydrogen Production by Glycerol Steam Reforming: How Mg Doping Affects the Catalytic Behaviour of $\mathrm{Ni} / \mathrm{Al}_{2} \mathrm{O}_{3}$ Catalysts. International Journal of Hydrogen Energy, 41, 157-166. http://dx.doi.org/10.1016/j.ijhydene.2015.12.009

[11] Lo, Y.C., Chen, X.J., Huang, C.Y., Yuan, Y.J. and Chang, J.S. (2013) Dark Fermentative Hydrogen Production with Crude Glycerol from Biodiesel Industry Using Indigenous Hydrogen-Producing Bacteria. International Journal of Hydrogen Energy, 38, 15815-15822. http://dx.doi.org/10.1016/j.ijhydene.2013.05.083

[12] Sarma, S.J., Brar, S.K., Sydney, E.B., Bihan, Y.L., Buelna, G. and Soccol, G.R. (2012) Microbial Hydrogen Production by Bioconversion of Crude Glycerol: A Review. International Journal of Hydrogen Energy, 37, 6743-6490. http://dx.doi.org/10.1016/j.ijhydene.2012.01.050

[13] Silva, J.M., Soria, M.A. and Madeira, L.M. (2016) Steam Reforming of Glycerol for Hydrogen Production: Modeling Study. International Journal of Hydrogen Energy, 41, 1408-1418. http://dx.doi.org/10.1016/j.ijhydene.2015.11.055

[14] Silva, J.M., Soria, M.A. and Madeira, L.M. (2015) Thermodynamic Analysis of Glycerol Steam Reforming for Hydrogen Production with in Situ Hydrogen and Carbon Dioxide Separation. Journal of Power Sources, 273, 423-430. 
http://dx.doi.org/10.1016/j.jpowsour.2014.09.093

[15] Aihara, M., Umida, H., Tsutsumi, A. and Yoshida, K. (1990) Kinetic Study of UT-3 Thermochemical Hydrogen Production Process. International Journal of Hydrogen Energy, 15, 7-11. http://dx.doi.org/10.1016/0360-3199(90)90124-H

[16] Le Valley, T.L., Richard, A.R. and Fan, M. (2014) The Progress in Water Gas Shift and Steam Reforming Hydrogen Production Technologies: A Review. International Journal of Hydrogen Energy, 39, 16983-17000. http://dx.doi.org/10.1016/j.ijhydene.2014.08.041

[17] Xu, Y., Ma, Y., Demura, M. and Hirano, T. (2016) Enhanced Catalytic Activity of $\mathrm{Ni}_{3} \mathrm{Al}$ Foils towards Methane Steam Reforming by Water Vapor and Hydrogen Pretreatments. International Journal of Hydrogen Energy, 41, 7352-7362. http://dx.doi.org/10.1016/j.ijhydene.2016.03.103

\section{Submit or recommend next manuscript to SCIRP and we will provide best service for you:}

Accepting pre-submission inquiries through Email, Facebook, LinkedIn, Twitter, etc.

A wide selection of journals (inclusive of 9 subjects, more than 200 journals)

Providing 24-hour high-quality service

User-friendly online submission system

Fair and swift peer-review system

Efficient typesetting and proofreading procedure

Display of the result of downloads and visits, as well as the number of cited articles

Maximum dissemination of your research work

Submit your manuscript at: http://papersubmission.scirp.org/ 